\title{
Integrative and complementary practices: interest of the academic community and challenges of medical education
}

\section{Práticas integrativas e complementares em saúde: interesse da comunidade acadêmica e os desafios do ensino médico}

\author{
Luiza Gomes Dantas Gurgel ${ }^{1}$ (D) | luiza-gurgel@hotmail.com \\ Alana Rebeca Bezerra Jessé1 (1) alana.rjesse@gmail.com \\ Djerlly Marques Araújo da Silva' (1) djerlly.marques@gmail.com \\ Pedro Sá Leitão Laporte Alencar ${ }^{1}$ (D) pedrolaporte2@gmail.com \\ Arturo de Pádua Walfrido Jordán ${ }^{1}$ (D) arturojordan@fps.edu.br \\ Nicolas Augusto Alves Daniel ${ }^{2}$ (D) coordenacaopics.recife@gmail.com
}

\begin{abstract}
Introduction: Traditional Complementary and Alternative Medicine (TCAM) encompass therapeutic resources of complex medical systems from different medical rationalities. This field of practice has gained greater visibility in recent times, with the increase in demand for health care that prioritizes a more comprehensive approach of human beings, encouraging the health professionals themselves to seek better training.

Objective: To evaluate the interest, the degree of knowledge and the attitude of students and teachers of the medical course towards the TCAM and the challenges for their effective teaching.

Method: This is a cross-sectional, descriptive study with a quantitative approach, which was carried out with 214 individuals, 21 of which were teachers and 193 students attending the first to the twelfth semesters of the medical course at a health education institution in Recife-PE. An online survey was used to assess the study participants regarding their learning sources and the level of interest on this topic, as well as the Portuguese version of the Integrative Medicine Attitude Questionnaire (IMAQ). The data were submitted to descriptive statistical analysis (frequency and percentage), using software $\mathrm{R}$, version 3.4.3. and LibreOffice.

Result: Among the study participants, $57.14 \%$ of teachers and $35.42 \%$ of students were aware of the Nacional TCAM Policy (PNPIC, Política Nacional de Práticas Integrativas e Complementares), $85.71 \%$ of the teachers and $91.7 \%$ of students considered TCAM to be crucial for Brazilian Unified Health System (SUS). Most considered the teaching of TCAM an important subject for the undergraduate medical course (90.48\% of teachers and $89.58 \%$ of students). The best known practices were yoga, phytotherapy and TCM/acupuncture and there was greater interest to learn yoga and TCM/acupuncture.

Conclusion: A large number of students and teachers have never had contact with TCAM. However, most are willing to recommend them to patients and family members and are willing to learn about the topic. Thus, it is recommended that more studies be performed on this topic and that it can corroborate for their inclusion in health courses' curriculum.
\end{abstract}

Keywords: Complementary Therapies; Education, Medical; Students, Medical; Medical Faculty; Unified Health System.

\section{RESUMO}

Introdução: As Práticas Integrativas e Complementares em Saúde (PICS) abrangem recursos terapêuticos de sistemas médicos complexos de diversas racionalidades médicas. Esse campo de práticas vem ganhando maior visibilidade nos últimos tempos com o aumento da procura por cuidados em saúde que priorizem a abordagem integral do ser humano, estimulando os próprios profissionais de saúde a buscar uma melhor formação.

Objetivo: Este estudo teve como objetivo avaliar o interesse, o grau de conhecimento e a atitude de discentes e docentes do curso de Medicina pelas PICS e os desafios para seu ensino efetivo.

Método: Trata-se de um estudo transversal, descritivo e com abordagem quantitativa, realizado com 214 indivíduos, sendo 21 docentes e 193 discentes do primeiro ao décimo segundo período do curso de Medicina de uma instituição de ensino de saúde de Recife, em Pernambuco. Utilizou-se um questionário em formato on-line que avaliou os sujeitos pesquisados quanto às fontes de aprendizado e ao nível de interesse sobre o tema. Adotou-se também a versão em português do instrumento Integrative Medicine Attitude Questionnaire (IMAQ). Os dados foram submetidos à análise estatística descritiva (frequência e porcentagem), com o auxílio dos softwares $R$ versão 3.4.3. e LibreOffice.

Resultado: Dentre os participantes do estudo, 57,14\% dos docentes e 35,42\% dos discentes afirmaram conhecer a Política Nacional de Práticas Integrativas e Complementares (PNPIC), e 85,71\% dos docentes e 91,7\% dos discentes consideraram as PICS fundamentais para o SUS. A maioria considerou o ensino das PICS importante para a graduação (90,48\% dos docentes e 89,58\% dos discentes). As práticas mais conhecidas foram a ioga, a fitoterapia e a MTC/acupuntura, e as que despertaram maior interesse para aprendizado foram a ioga e a MTC/acupuntura.

Conclusão: Um número elevado de discentes e docentes nunca teve contato com as PICS. No entanto, a maioria tem disposição em recomendar para pacientes e familiares, bem como vontade em aprender sobre o tema. Dessa forma, recomenda-se que mais trabalhos sejam realizados sobre a temática e que isso possa corroborar a sua inclusão na base curricular dos cursos de saúde.

Palavras-chave: Terapias Complementares; Educação Médica; Estudantes de Medicina; Docentes de Medicina; Sistema Único de Saúde.

${ }^{1}$ Faculdade Pernambucana de Saúde, Recife, Pernambuco, Brazil.

2 Prefeitura Municipal do Recife, Recife, Pernambuco, Brazil.

Chief Editor: Rosiane Viana Zuza Diniz. Associate Editor: Ana Cláudia Santos Chazan.

Received on 06/08/21; Accepted on 10/25/21. | Evaluated by double blind review process. 


\section{INTRODUCTION}

Integrative and complementary health practices comprise a heterogeneous set of therapeutic practices, knowledge and resources that encompass medical systems from different medical rationalities. This field is called Traditional/ Complementary and Alternative Medicine (TCAM) by the World Health Organization (WHO) and involves approaches that seek to stimulate natural mechanisms for health recovery and disease prevention through techniques that emphasize user embracement and a comprehensive view of the human being in their physical, mental, social and spiritual scope'.

In the late 1970s, the WHO created the Traditional Medicine Program to create policies in the $a^{2} a^{2}$. Since then, there is an effort to encourage Member States to implement public policies for the rational use of TCAM in health care systems, as well as the development of studies to better understand its safety and quality ${ }^{1}$. It was from this perspective that, in 2006, in Brazil, the National Policy on Integrative and Complementary Practices (PNPIC) was created in the Brazilian Unified Health System (SUS). The PNPIC, working with 29 currently regulated practices, legitimized the public offering of activities that were already used by the population ${ }^{3}$.

The PNPIC in SUS still has little support, such as low financial incentives, few investments in professional training, poor evaluation and monitoring. However, it is recognized by the WHO that the TCAM are effective in areas such as mental health, prevention and treatment of non-communicable diseases and improvement in the quality of life of people with chronic diseases, as well as the aging population. Even with all the challenges, the search for these techniques has been increasing. The pursuit of a balanced health through interventions focused on a holistic view is growing, especially when building a health system that seeks, in one of its three basic principles, comprehensive care ${ }^{4}$.

It is essential to highlight the reality of the TCAM in Recife, state of Pernambuco, Brazil, where the institution evaluated in this study is located. The history of work in the area precedes the PNPIC itself, being a pioneer in providing these practices linked to the Family Health Strategy, such as the Professor Guilherme Abath Comprehensive Health Care Unit (UCIS), founded in 2002, and which is currently the field of medical residency practice in family health, as well as the Municipal Policy of Integrative and Complementary Practices in Health in Recife, created in 2012, which further strengthens the presence of these practices in the local health network ${ }^{5,6}$.

Considering the scarcity of studies and the population's growing interest in these practices, it is important that this topic be taken to the academic environments. The practical reality, however, goes against the population's growing demand for alternative therapies: there are many physicians who are unable to answer questions raised by patients about the use of TCAM, or about their mechanisms of action, indications, drug interactions or even adverse effects of these therapies ${ }^{7}$.

To understand the challenges of teaching TCAM, the prejudice and lack of information present in medical education adopted in Brazil call for attention. Despite the changes achieved with the National Curriculum Guidelines (NCGs), medical education is still influenced by the Flexner reform from early $20^{\text {th }}$ century North America, which favored medical training associated to laboratory diagnoses, performance of exams and procedures and fragmentation of knowledge in search of more efficient training. Due to the mercantilization of health, this model spread throughout the West and, therefore, TCAM were excluded from undergraduate schools, as they were considered "non-scientific"

Although there is not enough research in Brazil on the teaching of TCAM at the undergraduate level, there are examples of medical schools worldwide that embrace them and even developed instruments to assess attitudes towards this topic, such as the Integrative Medicine Attitude Questionnaire (IMAQ) ${ }^{9}$.

Even with a medical curriculum that does not meet the need for the teaching on the subject, it was observed that, overall, medical students have favorable attitudes towards TCAM and wish to learn more on this subject. Additionally, they also consider the offer of TCAM in health services to be important and many students believe in the possibility of integrating them to the conventional Medicine ${ }^{10}$.

Therefore, this study aimed to assess the interest, level of knowledge and attitude of medical students and teachers towards TCAM and the challenges for their effective teaching. This information will allow the recognition of important issues in order to change the deficiency of TCAM in medical education in theoretical and practical scenarios.

\section{METHOD}

This is a cross-sectional, descriptive study with a quantitative approach, carried out at a medical school in Recife, state of Pernambuco, Brazil, which develops its pedagogical project based on the principles of active methodology, through the Problem-Based Learning (PBL) method, in agreement with the guidelines recommended by the Brazilian Unified Health System (SUS, Sistema Único de Saúde). This course is programmed for learning in a laboratory environment from the $1^{\text {st }}$ to the $4^{\text {th }}$ semester, in an outpatient hospital environment from the $5^{\text {th }}$ to the $8^{\text {th }}$ semesters and in a hospital setting, under supervised internship, from the $9^{\text {th }}$ to the $12^{\text {th }}$ semesters. 
The study population consisted of the students and teachers of the abovementioned medical course from the $1^{\text {st }}$ to the $12^{\text {th }}$ semesters, with a total of 1,084 students regularly enrolled in the institution, in any academic stage of the course, and a total of 88 teachers working in academic activities of the analyzed semesters (data from 2019). The non-probabilistic sample was defined by convenience, and consisted of 214 individuals, of which 21 were teachers and 193 students.

The study included people over 18 years of age, students who were enrolled in that medical course during the study period, and who were attending any of the course semesters, from the $1^{\text {st }}$ to the $12^{\text {th }}$ academic semesters; and teachers from that course, during the current period of this study. Students on a leave of absence were excluded from the analysis.

A questionnaire was used for data collection, consisting of: 1. sociodemographic and occupational data; 2. general knowledge about the TCAM in SUS and opinions and experiences, both in the academic environment and in medical practice, with all the practices that were part of the PNPIC; and 3. IMAQ9.

The IMAQ is an instrument that originated from the need to have a self-applicable, reliable and psychometrically capable way of measuring the attitude of students towards Integrative Medicine to provide educators with a useful tool to sensibly implement, evaluate and review Complementary Medicine curricula. In 2015, the questionnaire was validated for the Portuguese language ${ }^{9}$, which is the version used in this study. It uses the modified Likert scale format, containing 7 points, ranging from -3 to +3 , with -3 being equivalent to Strongly disagree and +3 Strongly agree. This instrument has a structure divided into two factors: the first is related to being open to new ideas and paradigms, containing 21 items - which is called "Openness" - and the second is related to the health professional's introspection values and the doctor-patient relationship - a factor called "Relationship" - containing 8 items. Therefore, the IMAQ contains a total of 29 items and scores negatively or positively.

The online survey was constructed using LimeSurvey and emails were sent to the entire academic community of the course. Another strategy used to increase the number of respondents was contact through a messaging application.

The creation of the database and its analysis were carried out using the LibreOffice program. The data were organized in three moments of analysis: 1. description of the respondents' profile: considering the participant's age, gender, activity performed at the institution, student's course semester and the teacher's medical training; 2 . knowledge and interest of teachers and students: knowledge of the TCAM that constitute the PNPIC, identification of known practices, those addressed in undergraduate school, the ones that arise interest in learning, those in which the participant already had a previous complementary training, source from which knowledge about TCAM was obtained, level of satisfaction with the knowledge provided by the course, level of elucidation and attainment and learning goals in the subject, considering TCAM as essential for SUS, belief in the need for teaching TCAM in undergraduate medical school, identification of participants who would recommend them to patients and/or family members, identification of teachers interested in addressing the topic in curricular activities and interested in training to teach TCAM; and 3. attitudes towards TCAM, such as openness to the topic and doctor-patient relationship.

For the statistical analysis, categorical variables were calculated as absolute (counts) and relative (percentages) frequencies. Data from the electronic questionnaire were submitted to the descriptive statistical analysis (frequency and percentage), with the aid of R software, version 3.4.3. and LibreOffice. The results are presented as tables. As for the results obtained from the IMAQ, the higher the score, the more positive are the attitudes towards TCAM.

This research complies with resolutions 466/2012 and $510 / 2016$ of the National Health Council and was approved by the Research Ethics Committee of FPS under the $n^{\circ}$ 3.495.554. All participants who met the eligibility criteria consented to participate in the study by agreeing with the Free and Informed Consent Form (FICF), included in the online questionnaire.

\section{RESULTS}

The sample consisted of 193 students and 21 teachers. This number of students corresponds to $17.8 \%$ of the 1,084 students enrolled in the medical course from the first to the twelfth semesters during the current study period. The number of teachers who answered the questionnaire corresponds to $23.8 \%$ of the staff of 88 teachers in this medical school. The gender distribution was 16 female teachers (76.2\%) and 134 female students (69.4\%) and 5 male teachers (23.8\%) and 59 male students (30.6\%). As for the course semester, 87 students $(45.1 \%)$ were enrolled between the $9^{\text {th }}$ and the $12^{\text {th }}$ semesters, $58(30.1 \%)$ between the $1^{\text {st }}$ and the $4^{\text {th }}$ semesters and $48(24.9 \%)$ between the $5^{\text {th }}$ and $8^{\text {th }}$ semesters. Regarding the specialties in health, 5 of the teachers that constitute the sample work in Primary Health Care (23.8\%) and 5 are pediatricians (23.8\%), 4 (19\%) work in the area of gynecology and obstetrics, 3 (14.3\%) in geriatrics or in a surgical specialty. Of the activities at the institution, $12(57.1 \%)$ are teachers of the regular modules, 4 (19\%) are teachers of the Primary Care Practice modules and 5 $(23.9 \%)$ are in coordinating activities in the course. 
Concerning the knowledge about the TCAM, 12 (57.1\%) teachers and 69 (35.8\%) students said they knew about the National Policy on Integrative and Complementary Practices (PNPIC). Yoga was the best known practice, both by the teachers $(n=17 ; 80.9 \%)$ and the students $(n=159 ; 82.4 \%)$, followed by medicinal plants and phytotherapy for teachers $(n=16 ; 76.2 \%)$ and meditation for students $(n=154 ; 79.8 \%)$. The source of obtaining knowledge about TCAM reported by 7 teachers (33.3\%) was through professionals not affiliated with the school, 4 (19.1\%) obtained it through individual studies, 3 (14.3\%) acquired it from mass media, 3 (14.3\%) had never had contact with them and 2 (9.6\%) had contact with this through activities within the school. As for the students, 110 (57.4\%) obtained knowledge about the TCAM from academic activities linked to the medical school, while 38 (19.7\%) stated that they had never had contact with the subject.

Of the 110 students who answered they had obtained knowledge about the TCAM during some academic activity provided by the school, 52 students (47.3\%) do not agree or strongly disagree that the knowledge provided by the institution was satisfactory in terms of safety in practical application. Moreover, 52 students (47.3\%) stated that the knowledge provided by the school did not have sufficiently clear educational and learning objectives.

Of the practices that were most frequently discussed during the undergraduate school period of the interviewed teachers, art therapy ( $\mathrm{N}=6 ; 28.57 \%)$, homeopathy ( $\mathrm{N}=5$; 23.8\%), Traditional Chinese Medicine (TCM)/acupuncture ( $N$ $=5 ; 23.8 \%)$, phytotherapy $(\mathrm{N}=4 ; 19 \%)$ and aromatherapy ( $N=4 ; 19 \%)$ are highlighted. The interviewed students indicated the approach in the academic environment of homeopathy ( $\mathrm{N}=53 ; 27.5 \%)$, of TCM/acupuncture ( $\mathrm{N}=46$; $23.8 \%)$, of phytotherapy $(\mathrm{N}=43 ; 22.3 \%)$, meditation $(\mathrm{N}=37$; $19.1 \%)$ and art therapy $(\mathrm{N}=35 ; 18.1 \%)$.

Of the most frequently used TCAM by both teachers and students who were interviewed, the following stand out: meditation - 101 (52.3\%) students and 9 (42.8\%) teachers; yoga - $76(39.4 \%)$ students and 8 teachers (38.1\%); phytotherapy - 67 (34.7\%) students and 7 (33.3\%) teachers; TCM/acupuncture - 51 (26.4\%) students and 8 (38.1\%) teachers; and homeopathy - $45(23.3 \%)$ students and 7 (33.3\%) teachers.

As for the interest in receiving theoretical and practical training to teach TCAM, 19 (90.5\%) of the interviewed teachers indicated an interest both in learning and in addressing TCAM with students in their curricular activities. It is noteworthy that $3(14.3 \%)$ of the interviewed teachers already have complementary training in meditation, 3 (14.3\%) in laying of hands and 2 (9.6\%) in Reiki. Of the students, 6 (3.1\%) have additional training in art therapy, 5 (2.6\%) in Reiki and 3 (1.5\%) in meditation.

Among the practices that arise greater interest in learning for, music therapy $(N=7 ; 33.33 \%)$, yoga $(N=6 ; 28.6 \%)$, TCM/acupuncture $(\mathrm{N}=6) 28.6 \%)$, homeopathy $(\mathrm{N}=5 ; 23.8 \%)$ and meditation ( $\mathrm{N}=5 ; 23.81 \%$ ) stand out. For the students, the practices that most frequently arise the desire to learn are TCM/acupuncture $(\mathrm{N}=92 ; 47.6 \%)$, yoga $(\mathrm{N}=78 ; 40.4 \%)$, phytotherapy ( $\mathrm{N}=76 ; 39.4 \%)$, meditation $(\mathrm{N}=76 ; 39.4 \%)$ and chiropractic care $(\mathrm{N}=74 ; 39.4 \%)$.

Most interviewees considered that TCAM are essential for SUS: 177 (91.7\%) of the students and $18(85.7 \%)$ of the teachers. Also, 173 (89.6\%) students and 19 (90.5\%) teachers considered that the teaching of TCAM is necessary in undergraduate medical school. All teachers and students interviewed stated that they would recommend some form of TCAM to their patients and/or family members.

Regarding the results obtained from the IMAQ, there was an average score of 31.17 (with the minimum value being -29 and the maximum, 75), with a median of 33.5 and standard deviation (SD) of 17.56. As for the categorization in the two factors, the item Openness, related to the opening to new ideas and paradigms, had an average score of 17.81 (minimum value of -25 and maximum of 53); median score of 18 and SD of 13.29 , while in the item Relationships, which deals with introspection and the doctor-patient relationship, the mean score was 13.36 (minimum value -15 and maximum value 24); median of 14 and SD of 6.92 .

Table 1. Knowledge and interests of medical school teachers about TCAM. Recife, Pernambuco, Brazil, in 2020.

\begin{tabular}{lcc}
\multicolumn{1}{c}{ Characteristic } & N & $\%$ \\
\hline Total number of teachers in the sample & 21 & 100 \\
\hline Area of expertise/professional specialization & & \\
Pediatrics & 5 & 23.8 \\
Primary Health Care & 5 & 23.8 \\
Gynecology and Obstetrics & 4 & 19.0 \\
Geriatrics & 3 & 14.3 \\
Surgery & 3 & 14.3 \\
\hline Knows about the PNPIC & 12 & 57.1 \\
\hline Best known TCAM & & \\
Yoga & 17 & 80.9 \\
Medicinal Plants and Phytotherapy & 16 & 76.2 \\
Meditation & 15 & 71.4 \\
Homeopathy & 15 & 71.4 \\
Music therapy & 15 & 71.4 \\
\hline
\end{tabular}


Table 1. (Continuation) Knowledge and interests of medical school teachers about TCAM. Recife, Pernambuco, Brazil, in 2020.

\begin{tabular}{|c|c|c|}
\hline Characteristic & $\mathbf{N}$ & $\%$ \\
\hline \multicolumn{3}{|l|}{ Source of knowledge about TCAM } \\
\hline $\begin{array}{l}\text { Professionals not linked to the educational } \\
\text { institution }\end{array}$ & 7 & 33.3 \\
\hline Individual studies & 4 & 19.0 \\
\hline Mass media & 3 & 14.3 \\
\hline Never had contact & 3 & 14.3 \\
\hline $\begin{array}{l}\text { Congresses, symposia, conferences or } \\
\text { other scientific meetings }\end{array}$ & 2 & 9.5 \\
\hline Theoretical module in primary care & 1 & 4.8 \\
\hline Exhibitions & 1 & 4.8 \\
\hline \multicolumn{3}{|l|}{ TCAM addressed during undergraduate school } \\
\hline Art therapy & 6 & 28.6 \\
\hline Homeopathy & 5 & 23.8 \\
\hline TCM/Acupuncture & 5 & 23.8 \\
\hline Medicinal Plants and Phytotherapy & 4 & 19.0 \\
\hline Aromatherapy & 4 & 19.0 \\
\hline \multicolumn{3}{|l|}{ Most frequently used TCAM } \\
\hline Meditation & 9 & 42.8 \\
\hline TCM/Acupuncture & 8 & 38.1 \\
\hline Yoga & 8 & 38.1 \\
\hline Medicinal Plants and Phytotherapy & 7 & 33.3 \\
\hline Homeopathy & 7 & 33.3 \\
\hline Reiki & 7 & 33.3 \\
\hline $\begin{array}{l}\text { Interest in addressing TCAM during teaching } \\
\text { activities }\end{array}$ & 19 & 90.5 \\
\hline $\begin{array}{l}\text { Interest in receiving training for the teaching } \\
\text { of TCAM in teaching activities }\end{array}$ & 19 & 90.5 \\
\hline
\end{tabular}

Has had complementary training

\begin{tabular}{lcc} 
Meditation & 3 & 14.3 \\
Laying on of hands & 3 & 14.3 \\
Reiki & 2 & 9.6 \\
Medicinal Plants and Phytotherapy & 1 & 4.7 \\
Shantala & 1 & 4.7 \\
\hline I would like to learn & 7 & 33.3 \\
Music therapy & 6 & 28.6 \\
Yoga & 6 & 28.6 \\
TCM/Acupuncture & 5 & 23.8 \\
Meditation & 5 & 23.8 \\
\hline Homeopathy & 18 & 85.7 \\
\hline Considers that TCAM are essential for the SUS & 19 & 90.5 \\
\hline $\begin{array}{l}\text { Believes that the teaching of TCAM is } \\
\text { necessary in undergraduate medical school }\end{array}$ & 21 & 100 \\
\hline $\begin{array}{l}\text { Would recommend TCAM to patients and/or } \\
\text { family members }\end{array}$ & &
\end{tabular}

Table 2. Knowledge and interests of medical students about TCAM. Recife, Pernambuco, Brazil, in 2020.

\begin{tabular}{lcc}
\hline \multicolumn{1}{c}{ Characteristic } & N & $\%$ \\
\hline Total number of students in the sample & 193 & 100 \\
\hline Knows about the PNPIC & 69 & 35,8 \\
\hline Best known TCAM & & \\
Yoga & 159 & 82,4 \\
Meditation & 154 & 79,8 \\
TCM/Acupuncture & 145 & 75,1 \\
Medicinal Plants and Phytotherapy & 130 & 67,3 \\
Music therapy & 124 & 64,2 \\
\hline
\end{tabular}

Source of knowledge about the TCAM

Exhibitions

$57 \quad 29,5$

Never had contact

$38 \quad 19,7$

Theoretical module in primary care $\quad 33 \quad 17,1$

$\begin{array}{lll}\text { Mass media } & 15 & 7,8\end{array}$

$\begin{array}{lll}\text { Tutoring module } & 11 & 6,7\end{array}$

Scientific meetings $\quad 11 \quad 5,7$

$\begin{array}{lll}\text { Integration activity between classes } & 6 & 3,1\end{array}$

$\begin{array}{lll}\text { Others } & 6 & 3,1\end{array}$

$\begin{array}{lll}\text { Professionals not linked to the } & 5 & 2,6\end{array}$

$\begin{array}{lll}\text { educational institution } & 5 & 2,6\end{array}$
\begin{tabular}{l}
$\begin{array}{l}\text { Rotation in Family Health Unit linked to } \\
\text { the educational institution }\end{array}$ \\
\hline
\end{tabular}

The knowledge provided by the experiences in College is sufficient to have security during 110 its practical application

$\begin{array}{lll}\text { Agree/ Strongly agree } & 27 & 24,5\end{array}$

$\begin{array}{lll}\text { Neither agree nor disagree } & 31 & 28,2\end{array}$

$\begin{array}{lll}\text { Disagree Strongly /disagree } & 52 & 47,3\end{array}$

The teaching and learning objectives of this 110 topic were elucidated and achieved

$\begin{array}{lll}\text { Agree/ Strongly agree } & 27 & 24,5\end{array}$

$\begin{array}{lll}\text { Neither agree nor disagree } & 31 & 28,2\end{array}$

$\begin{array}{lll}\text { Disagree/ Strongly disagree } & 52 & 47,3\end{array}$

TCAM addressed during undergraduate school

Homeopathy $\quad 53 \quad 27,5$

TCM/Acupuncture $46 \quad 23,8$

Medicinal Plants and Phytotherapy $43 \quad 22,3$

$\begin{array}{lll}\text { Meditation } & 37 & 19,1\end{array}$

$\begin{array}{lll}\text { Art therapy } & 35 & 18,1\end{array}$

Most often used TCAM

Meditation $\quad 101 \quad 52,3$

$\begin{array}{lll}\text { Yoga } & 76 & 39,4\end{array}$

Medicinal Plants and Phytotherapy $\quad 67 \quad 34,7$

TCM/Acupuncture $\quad 51 \quad 26,4$

Homeopathy $45 \quad 23,3$ 
Table 2. (Continuation) Knowledge and interests of medical students about TCAM. Recife, Pernambuco, Brazil, in 2020 .

\begin{tabular}{|c|c|c|}
\hline Characteristic & $\mathbf{N}$ & $\%$ \\
\hline \multicolumn{3}{|l|}{ I would like to learn } \\
\hline TCM/Acupuncture & 92 & 47,6 \\
\hline Yoga & 78 & 40,4 \\
\hline Medicinal Plants and Phytotherapy & 76 & 39,4 \\
\hline Meditation & 76 & 39,4 \\
\hline Chiropractic care & 74 & 39,4 \\
\hline \multicolumn{3}{|l|}{ Has had complementary training } \\
\hline Art therapy & 6 & 3,1 \\
\hline Reiki & 5 & 2,6 \\
\hline Meditation & 3 & 1,5 \\
\hline Floral therapy & 3 & 1,5 \\
\hline Medicinal Plants and Phytotherapy & 2 & 1,0 \\
\hline TCM/Acupuncture & 2 & 1,0 \\
\hline Considers that TCAM are essential for the SUS & 177 & 91,7 \\
\hline $\begin{array}{l}\text { Believes that teaching TCAM is necessary in } \\
\text { undergraduate medical school }\end{array}$ & 173 & 89,6 \\
\hline $\begin{array}{l}\text { Would recommend TCAM to patients and/or } \\
\text { family members }\end{array}$ & 193 & 100 \\
\hline
\end{tabular}

\section{DISCUSSION}

The profile analysis identifies a majority of female participants, which is in line with the national scenario of the feminization of medical work ${ }^{11}$. Regarding the teachers, there is a predominance of primary care workers, while the students were mainly in the internship phase of the course, a scenario that favors greater familiarization with TCAM, as they are majorly offered at the primary level of care and this group has more experience in this environment. In it, the values are focused on health with the perspective of community and comprehensive care and resonate with the different rationalities that encompass the $\mathrm{TCAM}^{8}$. Thus, it is stated that they are participants who represent part of the academic body with a greater chance of having had contact with TCAM during the undergraduate medical school.

Regarding the $\mathrm{PNPIC}^{12}$, there is a gap in the academic body's knowledge regarding the policy. This scenario draws attention when considering the municipality where the institution is located. With health units such as the UCIS and specific municipal policies for $\mathrm{TCAM}^{5,6,8}$ that preceded the PNPIC or that have been improved since then, it shows there is a disassociation between education and health services,

Figure 1. Attitudes of academic staff towards TCAM based on the IMAQ. Recife, Pernambuco, Brazil, in 2020.

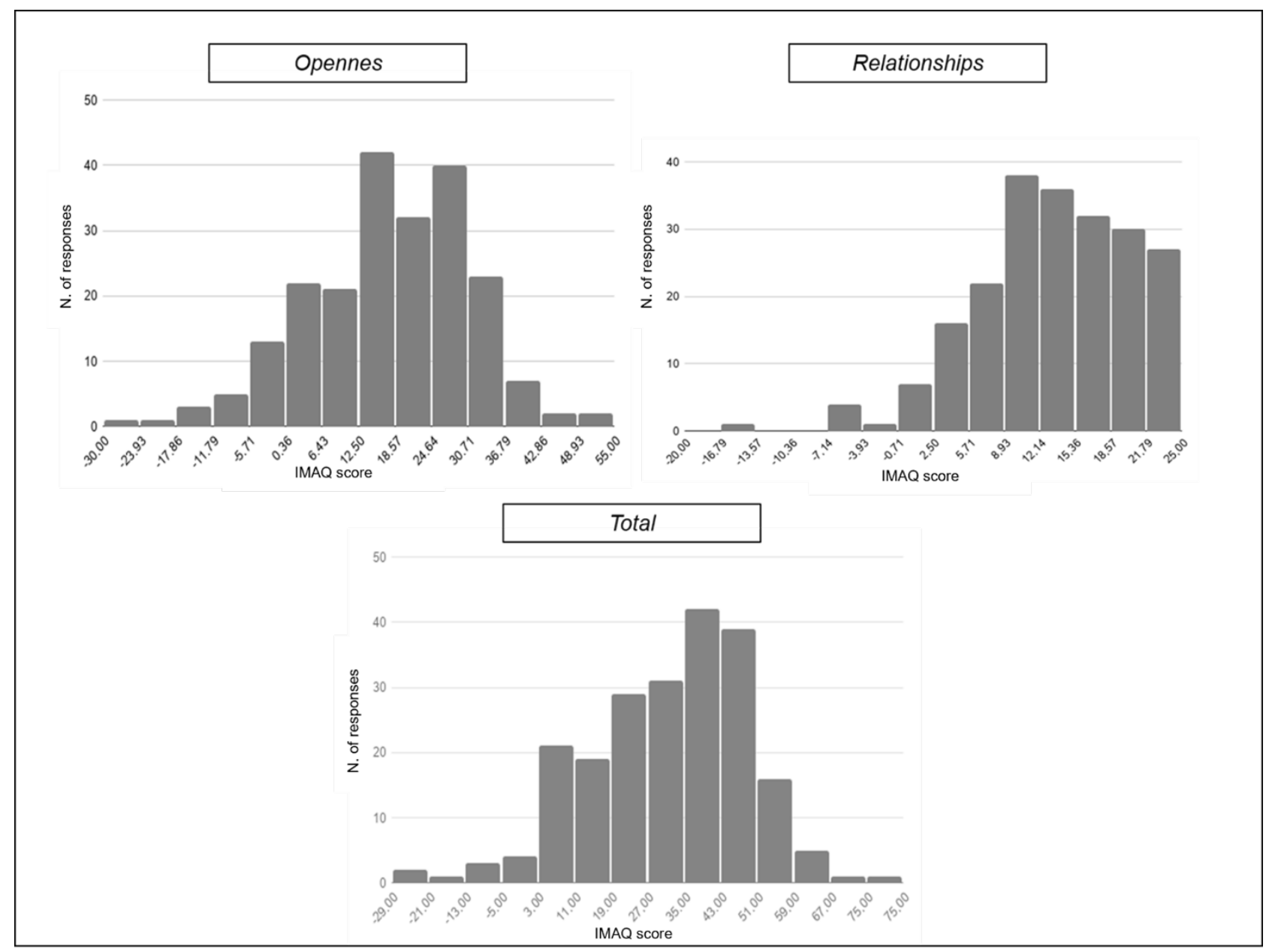


in addition to the lack of knowledge about the care that the population already has access to and tends to increasingly seek ${ }^{13}$. In order to have a health network that ideally encompasses TCAM, training for this purpose is necessary, linking the teaching-service-community. Nevertheless, the participants have favorable attitudes towards the inclusion of the topic in undergraduate school, since most consider the TCAM as essential and support a greater inclusion of their teaching in the curriculum, which is also recommended by researchers ${ }^{13}$.

Another challenge identified was related to the environment for obtaining knowledge on the subject by the teachers: most resorted to individual studies or contacts outside the institution, with a large number having superficial contact through the mass media or even never having had contact. Moreover, the students' claim comes to question the quality of the provided training, since some of them do not feel secure in the practical application of the knowledge obtained and affirm that there are no clear learning objectives to guide the studies. In addition to these facts, however, all participants stated that they would recommend at least some of the TCAM. Therefore, considering what the NCGs ${ }^{14}$ established for adequate medical education, there is a weakness and lack of training regarding the subject, with potential risks for medical practice, since there is no sufficient knowledge about the possible risks or adverse effects to make the correct recommendation of these therapies ${ }^{7,15}$.

Examples of medical schools and medical residency programs that include TCAM in the course syllabus can be found $^{16}$, but the training of tutors and preceptors is critical. The study showed that there is interest in training on the subject, which demonstrates the positive attitudes towards professional qualification. A small part of the sample has had complementary training in some of the practices and identifying them is important when thinking about the need for collaboration between professionals to aid the breaking of prejudice and for the applicability of TCAM.

In relation to each individualized practice, there was more general knowledge identified around the most widespread practices and those with a greater amount of clinical research proving their health benefits ${ }^{5,6}$, as in the case of Yoga, medicinal plants, meditation, as well as practices that already have established medical residency programs in Brazil, such as homeopathy and acupuncture/Traditional Chinese Medicine ${ }^{13}$. It is also worth drawing a parallel with the practices most frequently used by the participants and the interest in learning them, which are practically the same, showing that there is a degree of association between the use of certain practices, arousing the interest in learning them, and attitudes that are favorable to their use and recommendation.
As for the data related to the IMAQ, it can be observed that the positive total mean score, with a standard deviation that does not show extreme variations between minimum and maximum values, reinforces the existence of favorable attitudes towards more holistic approaches. Considering the factors of this instrument separately, in relation to openness to new ideas and paradigms, it can be said that despite the positive average value, it is still has smaller significance in relation to the maximum possible value, a fact that is associated with the resistance towards topics that deviate from the exclusively biomedical approach. Regarding the introspection factor and the doctor-patient relationship, the IMAQ demonstrates that, proportionally, there are more positive attitudes in comparison to the openness to topics such as TCAM.

It is important to emphasize that the results obtained from the assessed population cannot be taken as a representation of the entire universe of the target population, due to the selection bias identified during the questionnaire application. As this is a survey-type study applied through an online questionnaire on a virtual platform provided by the educational institution, there was the technological advantage of repeatedly distributing the questionnaire to all students and teachers, however, the restricted virtual format made the initially designed questionnaire become longer, a contributing factor to the non-response rate $\mathrm{e}^{17,18}$, as well as discrepancies between the number of respondents from different periods of the course. Thus, the data analyzed here are representative only of the studied population and should not be extrapolated or taken as a concrete reality for the general public.

The assessment of knowledge, interests and attitudes of teachers and students about TCAM is a field that is little explored by health professionals in the medical education process. The results presented in this research are consistent with previous studies $^{14}$ that showed little knowledge of TCAM by health professionals and students. This is linked to the perpetuation of prejudice originated from the medical education reforms of the last century and the lack of learning on the topic throughout undergraduate school ${ }^{13,15}$, as consequence of the Flexner Report and its historical influence on Brazilian education. Currently, with the increasing inclination to break away from the diseasecentered health model and limited hospital training, and with the changes in education where primary and secondary levels of health care now have greater space in undergraduate school, having humanization and management of care as central agendas, there is room to develop TCAM ${ }^{14}$. Therefore, this study is an important step towards improving and enabling the official implementation of TCAM teaching within the medical curriculum. The TCAM have the potential to be an important tool for the needed resignification of medical education ${ }^{5,8,13}$. 


\section{CONCLUSIONS}

The results obtained through this study demonstrated that there is little knowledge about TCAM among the academic medical community. Despite this fact, most teachers and students would recommend the use of TCAM to their patients and understand their importance for SUS. The positive evaluation from the IMAQ shows that the academic community has interest in acquiring more knowledge related to integrative practices, despite being less pronounced, due to the lack of this subject in the training process.

The lack of theoretical-practical knowledge of students and teachers on the subject is prominent. Introducing complementary therapies in the curricular base of the medical course would result in a better educational debate around the importance of TCAM in medical undergraduate school and would contribute to a better qualification of future health professionals, so that they are better prepared to provide comprehensive care, considering the increased demand for integrative and complementary practices, which go beyond the biomedical rationality.

\section{AUTHORS' CONTRIBUTION}

All authors contributed substantially to the study conception, planning, data analysis, interpretation, drafting of the manuscript and critical review of its content.

\section{CONFLICTS OF INTEREST}

The authors declare no conflicts of interest.

\section{SOURCES OF FUNDING}

The authors declare no sources of funding.

\section{REFERENCES}

1. Brasil. Relatório do $1^{\circ}$ Seminário Internacional de Práticas Integrativas e Complementares em Saúde - PNPIC. Série C. Projetos, programas e relatórios. Brasília: Ministério da Saúde; 2009 [access in 08 jun 2021]. Available from: http://bvsms.saude.gov.br/bvs/publicacoes/seminario_ praticas_integrativas_complementares_saude.pdf.

2. Badri M, Dissanayake DMRD, Kao FF. The promotion and development of traditional medicine. Geneva: World Health Organization; 1978 [access in 08 jun 2021]. Available from: http://whqlibdoc.who.int/trs/WHO_ TRS_622.pdf.

3. Brasil. Política Nacional de Práticas Integrativas e Complementares no SUS. 2a ed. Brasília: Ministério da Saúde; 2015 [access in 08 jun 2021]. Available from: http://bvsms.saude.gov.br/bvs/publicacoes/politica_ nacional_praticas_integrativas_complementares_2ed.pdf.

4. De Sousa IMC, Tesser CD. Medicina tradicional e complementar no Brasil: inserção no Sistema Único de Saúde e integração com a atenção primária. Cad Saude Publica. 2017;33(1):1-15 [access in 08 jun 2021]. Available from: http://cadernos.ensp.fiocruz.br/csp/artigo/13/medicina-tradicionale-complementar-no-brasil-insercao-no-sistema-unico-de-saude-eintegracao-com-a-atencao-primaria.
5. Aroucha EBL. Práticas Integrativas e Complementares: o interesse em formação dos profissionais da Estratégia de Saúde da Família [monografia]. Recife: Instituto Aggeu Magalhães, Fundação Oswaldo Cruz; 2012 [access in 08 jun 2021]. Available from: https://www.cpqam.fiocruz. br/bibpdf/2012aroucha-ebl.pdf.

6. Santos FAS, De Sousa IMC, Gurgel IGD, Bezerra AFB, De Barros NF Política de práticas integrativas em Recife: análise da participação dos atores. Rev Saude Publica. 2011;45(6):1154-9 [access in 08 jun 2021]. Available from: http://www.scielo.br/scielo.php?script=sci_ arttext\&pid=S0034-89102011000600018.

7. Silverstein $D D$, Spiegel AD. Are physicians aware of the risks of alternative medicine? J Community Health. 2001;26(3):159-74 [access in 08 jun 2021] Available from: https://pubmed.ncbi.nlm.nih.gov/11478563.

8. Dos Santos ACD. Elaboração e validação de uma matriz de competências em Práticas Integrativas e Complementares em Saúde para um programa de terceiro ano opcional de residência em Medicina de Família e Comunidade [dissertação]. Recife: Instituto Aggeu Magalhães, Fundação Oswaldo Cruz; 2019 [access in 08 jun 2021]. Available from: https://profsaude-abrasco.fiocruz.br/tcm/elaboracao-validacao-matrizcompetencias-praticas-integrativas-complementares-saude-programa.

9. Pinheiro LDSS. Validação de campo do Integrative Medicine Attitude Questionnaire (IMAQ) para uso no Brasil [dissertação]. Porto Alegre: Pontifícia Universidade Católica do Rio Grande do Sul; 2015 [access in 08 jun 2021]. Available from: http://tede2.pucrs.br/tede2/handle/tede/6325.

10. Greiner KA, Murray JL, Kallail KJ. Medical student interest in alternative medicine. J Altern Complement Med. 2000;6(3):231-4 [access in 08 jun 2021]. Available from: https://pubmed.ncbi.nlm.nih.gov/10890331.

11. Scheffer M, Cassenote A, Guilloux AGA, Miotto BA, Mainardi GM Matijasevich $A$, et al. Demografia médica no Brasil 2018. São Paulo: Departamento de Medicina Preventiva da Faculdade de Medicina da USP Conselho Regional de Medicina do Estado de São Paulo, Conselho Federal de Medicina; 2018 [access in 08 jun 2021]. Available from: https://jornal usp.br/wp-content/uploads/DemografiaMedica2018.pdf.

12. Brasil.Portaria ${ }^{\circ} 702$, de 21 de março de 2018. Altera a Portaria de Consolidação n०2/GM/MS, de 28 de setembro de 2017, para incluir novas práticas na Política Nacional de Práticas Integrativas e Complementares - PNPIC. Diário Oficial da União; 56 mar 2018 [access in 08 jun 2021]. Available from: http:// bvsms.saude.gov.br/bvs/saudelegis/gm/2018/prt0702_22_03_2018.html.

13. Teixeira $M Z$, Lin CA. Educação médica em terapêuticas não convencionais Rev Med (São Paulo). 2013;92(4):224-35 [access in 08 jun 2021]. Available from: https://www.revistas.usp.br/revistadc/article/view/80004

14. Brasil. Resolução n³, de 20 de junho de 2014. Institui Diretrizes Curriculares Nacionais do Curso de Graduação em Medicina e dá outras providências. Diário Oficial da União; jun 2014 [access in 08 jun 2021]. Available from: http://portal.mec.gov.br/escola-de-gestores-da-educacao-basica/323secretarias-112877938/orgaos-vinculados-82187207/20138-ces-2014.

15. Giveon SM, Liberman N, Klang S, Kahan E. A survey of primary care physicians' perceptions of their patients' use of complementary medicine. Complement Ther Med. 2003;11(4):254-60 [access in 08 jun 2021]. Available from: https://pubmed.ncbi.nlm.nih.gov/15022662.

16. Christensen MC, De Barros NF. Medicinas alternativas e complementares no ensino médico: revisão sistemática. Rev Bras Educ Med. 2010;34(1):97105 [access in 08 jun 2021]. Available from: https://www.scielo.br/scielo. php?pid=S0100-55022010000100012\&script=sci_abstract\&tIng=pt.

17. Freitas $\mathrm{H}$, Oliveira $M$, Saccol AZ, Moscarola J. O método de pesquisa survey. Revista de Administração da USP. 2000;3(3):105-12 [access in 08 jun 2021] Available from: http://www.ufrgs.br/gianti/files/artigos/2000/2000_092_ RAUSP.PDF.

18. Cendón BV, Ribeiro NA, Chaves CJ. Pesquisas de survey: análise das reações dos respondentes. Informação \& Sociedade: Estudos. 2014;24(3):29-48 [access in 08 jun 2021]. Available from: https://periodicos.ufpb.br/ojs/ index.php/ies/article/view/19963.

This is an Open Access article distributed under the terms of the Creative Commons Attribution License, which permits unrestricted use, distribution, and reproduction in any medium, provided the original work is properly cited. 